\title{
Dietary level of cull pinto beans on animal performance, digestibility, and energy balance of pregnant-lactating hair ewes
}

\author{
Francisco Castillo Rangel ${ }^{1}$, Guillermo Villalobos Villalobos ${ }^{1 *}$, David Domínguez Díaz ${ }^{1}$, Juan \\ Ángel Ortega Gutiérrez¹, Sandra Rodríguez Piñeros', Gabriela Corral Flores ${ }^{1}$
}

${ }^{1}$ Universidad Autónoma de Chihuahua, Facultad de Zootecnia y Ecología, Chihuahua, Chihuahua, Mexico.

\begin{abstract}
The objective of this study was to evaluate the effect of three levels of cull pinto beans (CPB) on animal performance, energy balance, and digestibility of hair ewes during pregnancy-lactation. One hundred and sixty-eight Pelibuey ewes were used (105 multiparous and 63 primiparous). Seven ewes of each type were randomly assigned to each of the 24 pens. Then, the twenty-four pens were randomly assigned to one of three treatments. Treatments were assigned on DM basis at: $0 \mathrm{~g} \mathrm{~kg}^{-1}$ of CPB in the supplement; $250 \mathrm{~g} \mathrm{~kg}^{-1}$ of CPB in the supplement; and $500 \mathrm{~g} \mathrm{~kg}^{-1}$ of CPB in the supplement. Data was analyzed by using the PROC MIXED of SAS. Lamb birth and weaning weight were also evaluated with the GLM procedure of SAS. All variables were analyzed as a completely randomized design. No differences among treatments were observed for body weight, body condition score, non-esterified fatty acids, and body weaning weight. During late pregnancy, dry matter intake was different among treatments, but it was similar during lactation. Body birth weight was different among treatments and showed a quadratic effect. At day 30 of lactation, a treatment effect was found for digestibility of dry matter (DM). At the end of lactation, digestibility of crude protein was different among treatments. In day 60 of lactation, differences among treatments were found for digestibility of neutral detergent fiber. Due to equal ewe performance among treatments of CPB and its low cost, its use is recommended in hair ewe feeding for these productive stages: $500 \mathrm{~g} \mathrm{~kg}^{-1} \mathrm{DM}$ of the supplement during pregnancy and $400 \mathrm{~g} \mathrm{~kg}^{-1} \mathrm{DM}$ during lactation.
\end{abstract}

Key Words: legume, ovines, Phaseolus vulgaris, sheep

\section{Introduction}

Intensification of ethanol production has led to an increase in the price of animal feed, which produces a reduction in profitability affecting all sheep producers in Mexico. As a result, producers start looking for new alternatives to feed their animals. Grain legumes has been one of the strategies to alleviate the effect of under nutrition (Dixon and Hosking 1992). Recently, cull pinto beans (CPB; Phaseolus vulgaris L.) has become a solution for the market crisis of traditional animal feed supplementation (Castillo, 2011). In Mexico, bean grains that do not meet the quality standards for human consumption are used for animal feeding, since they represent a good source of protein, some vitamins and minerals, and complex carbohydrates; however, these nutritional components also

Received: September 7, 2016

Accepted: March 25, 2017

*Corresponding author: gvilla@uach.mx

Copyright (C) 2018 Sociedade Brasileira de Zootecnia. This is an Open Access article distributed under the terms of the Creative Commons Attribution License (http://creativecommons.org/licenses/by/4.0/), which permits unrestricted use, distribution, and reproduction in any medium, provided the original work is properly cited. contain anti-nutritional factors such as protease inhibitors, polyphenols, lectins, and phytic acid, among others (Mejía et al., 2003). Williams et al. (1984) found lectin antibodies in beef cattle, suggesting its absorption. In other study, Villalobos et al. (2010) found that CPB affected dry matter intake (DMI) in lambs and as CPB level increased, average daily gain (ADG) decreased. Similar results were presented by Rush et al. (1998), who reported a decrease in ADG as level of beans increased in steer diets. There is no available information about feeding ewes with cull pinto beans. The hypothesis was that the inclusion of CPB in the diet maintains animal performance in pregnant-lactating hair ewes. Therefore, the objective of this study was to evaluate the effect of three levels of CPB on performance, digestibility, and energy balance of hair ewes at the end of pregnancy and during lactation.

\section{Material and Methods}

All procedures involving animals were approved by local official techniques for animal care (NOM-051-ZOO1995: Humanitarian care of animals during mobilization of animals; and NOM-024-ZOO-1995: Animal health 
stipulations and characteristics during transportation of animals).

One hundred and sixty-eight Pelibuey ewes were used for the experiment (105 multiparous and 63 primiparous). Initially, all ewes were identified, vaccinated with a threeway clostridial vaccine (Bacterina triple bovina, BioZoo S A de C V, Zapopan, Jalisco, México), treated for internal and external parasites with ivermectin (Iverfull, Aranda Salud Animal, Querétaro, Querétaro, México), and received ADE vitamins. Ewes were classified according to the number of pregnancies in multiparous and primiparous. Within each type, seven ewes were randomly assigned to one of twenty-four pens (outdoors; $6 \times 7 \mathrm{~m}$ ). Then, five multiparous pens and three primiparous pens were randomly assigned to one of three treatments. Treatments were (DM basis): $0 \mathrm{~g} \mathrm{~kg}^{-1}$ of CPB in the supplement (control); $250 \mathrm{~g} \mathrm{~kg}^{-1}$ of CPB in the supplement (CB25); and $500 \mathrm{~g} \mathrm{~kg}^{-1}$ of CPB in the supplement (CB50). Animals were gradually adjusted to the supplement during pregnancy $\left(0.45 \mathrm{~kg} \mathrm{ewe}^{-1}\right)$ and lactation $\left(0.96 \mathrm{~kg} \mathrm{ewe}^{-1}\right)$, respectively. Supplement was offered daily at $10.00 \mathrm{~h}$ and formulated to contain [ME] of $2.8 \mathrm{Mcal} \mathrm{kg}{ }^{-1} \mathrm{DM}$ and [CP] of $154 \mathrm{~g} \mathrm{~kg}^{-1} \mathrm{DM}$ (NRC, 2006) during pregnancy (Table 1) and [ME] of $2.8 \mathrm{Mcal} \mathrm{kg}^{-1} \mathrm{DM}$ and [CP] of $218 \mathrm{~g} \mathrm{~kg}^{-1} \mathrm{DM}$ (NRC, 2006) during lactation (Table 1). Supplement was prepared weekly and CPB was cracked. Forage (alfalfa hay) was offered ad libitum. Ewes were allowed free access to water. Creep feeding was offered to lambs once they were 45 days old. Diets were formulated to contain at least [ME] of $2.83 \mathrm{Mcal} \mathrm{kg}^{-1} \mathrm{DM}$ and [CP] of
$262 \mathrm{~g} \mathrm{~kg}^{-1}$ DM with $200 \mathrm{~g} \mathrm{~kg}^{-1}$ of forage and $800 \mathrm{~g} \mathrm{~kg}^{-1}$ of concentrate (Table 2). During the experiment, 13 ewes (four from control, six from CPB25, and three from CPB50 groups) were removed from the experiment because of respiratory diseases that were not related with the treatments. During lactation, primiparous ewes from the CPB50 group presented mechanic diarrheas which were associated to the high intake of CPB in the diet. Due to the presence of diarrheas, the diet was reduced to $400 \mathrm{~g} \mathrm{~kg}^{-1}$ of CPB in the CPB50 group with no modification in the quantity of supplement offered per ewe per day (Table 3).

Ewes were weighed eight days before programmed calving. The first weighing was performed during lactation nine days after calving; the next weightings were scheduled in periods of 14 days until weaning to obtain changes in body weight. During each period, body condition score (BCS) was measured (Russel et al., 1969). Dry matter intake was measured daily in each pen and both lamb birth weight (LBW) and lamb weaning weight (LWW) were evaluated as well ( $65 \pm 3$ days of age).

In the laboratory, $\mathrm{CPB}$ and feed samples were ground in a Wiley mill (1-mm screen; Wiley mill model 4, Thomas Scientific, Swedesboro, NJ) and subjected to all or part of the following analysis: DM, organic matter $(\mathrm{OM}), \mathrm{CP}$, crude fiber, and ether extract (methods 934.01, 942.05, 976.05, 962.09, and 920.39, respectively; AOAC, 2003). Acid detergent fiber (ADF) and neutral detergent fiber (NDF) were determined following the procedure proposed by Van Soest et al. (1991) with an Ankom 200 fiber

Table 1 - Supplement ingredients and chemical composition (dry matter basis) of diets for pregnant-lactating hair ewes fed cull pinto beans (CPB; Phaseolus vulgaris)

\begin{tabular}{|c|c|c|c|c|c|c|}
\hline \multirow{3}{*}{ Item } & \multicolumn{6}{|c|}{ Treatment $^{1}$} \\
\hline & \multicolumn{2}{|c|}{ Control } & \multicolumn{2}{|c|}{$\mathrm{CB} 25$} & \multicolumn{2}{|c|}{ CB50 } \\
\hline & Pregnancy & Lactation & Pregnancy & Lactation & Pregnancy & Lactation \\
\hline \multicolumn{7}{|l|}{ Ingredient ( $\left.\mathrm{g} \mathrm{kg}^{-1} \mathrm{DM}\right)$} \\
\hline Cull pinto beans & 0 & 0 & 253.8 & 266.0 & 518.0 & 515.0 \\
\hline Ground sorghum & 668.0 & 347.0 & 626.0 & 176.0 & 421.0 & 251.0 \\
\hline Corn dried distillers' grain & 303.0 & 471.0 & 88.0 & 443.0 & 35.0 & 51.0 \\
\hline Cottonseed meal & 0 & 157.0 & 0 & 91.0 & 0 & 159.0 \\
\hline Salt & 14.0 & 12.0 & 14.0 & 12.0 & 15.0 & 12.0 \\
\hline Mineral premix ${ }^{2}$ & 14.0 & 12.0 & 14.0 & 12.0 & 15.0 & 12.0 \\
\hline \multicolumn{7}{|c|}{ Calculated chemical composition ( $\left.\mathrm{g} \mathrm{kg}^{-1} \mathrm{DM}\right)$} \\
\hline Crude protein & 154.0 & 218.0 & 154.0 & 218.0 & 154.0 & 218.0 \\
\hline Metabolizable energy $\left(\mathrm{Mcal} \mathrm{kg}^{-1}\right)$ & 2.8 & 2.8 & 2.8 & 2.8 & 2.8 & 2.8 \\
\hline $\mathrm{Ca}$ & 2.5 & 2.5 & 2.2 & 2.3 & 2.0 & 2.1 \\
\hline $\mathrm{P}$ & 5.7 & 6.5 & 4.5 & 5.1 & 3.5 & 5.0 \\
\hline \multicolumn{7}{|l|}{ Feed offered $(\mathrm{kg})$} \\
\hline Supplement & 0.42 & 0.96 & 0.42 & 0.96 & 0.42 & 0.96 \\
\hline Forage & \multicolumn{2}{|c|}{ Ad libitum } & \multicolumn{2}{|c|}{ Ad libitum } & \multicolumn{2}{|c|}{ Ad libitum } \\
\hline
\end{tabular}

DM - dry matter.

${ }^{1}$ Treatments: Control $=0 \mathrm{~g} \mathrm{~kg}^{-1}$ of CPB in the supplement; $\mathrm{CB} 25=250 \mathrm{~g} \mathrm{~kg}^{-1}$ of CPB in the supplement; $\mathrm{CB} 50=500 \mathrm{~g} \mathrm{~kg}^{-1}$ of CPB in the supplement.

${ }^{2}$ Mineral premix: P, $120 \mathrm{~g} \mathrm{~kg}^{-1}$; Ca, $115 \mathrm{~g} \mathrm{~kg}^{-1}$; Mg, 6 g kg-1; Mn, 2160 ppm; Zn, 2850 ppm; Fe, 580 ppm; Cu, 1100 ppm; I, 102 ppm; Co, 13 ppm; Se, 9 ppm; vitamin A, $220000 \mathrm{IU} \mathrm{kg}^{-1}$; and vitamin E, $245000 \mathrm{IU} \mathrm{kg}^{-1}$. 
analyzer (Ankom Technology, Fairport, NY). Minerals were determined by inductively coupled plasma atomic emission spectroscopy.

Digestibility of DM, CP, and NDF were measured eight days before lambing and on days 35 and 65 post partum. Eight ewes per treatment (four multiparous and four primiparous) were randomly selected for this trial using the same treatments of the performance experiment. Animals were kept in individual pens $(1.5 \times 1 \mathrm{~m})$ and fed forage ad libitum with the same amount of supplement in each period as used in the previous experiment (Tables 1 and 2). Animals were allowed free access to water. The experimental period for each sampling was eight days in length, with five days for DMI measurements and three

Table 2 - Creep feeding ingredients and calculated chemical composition

\begin{tabular}{|c|c|}
\hline Item & $\mathrm{g} \mathrm{kg}^{-1} \mathrm{DM}$ \\
\hline \multicolumn{2}{|l|}{ Ingredient } \\
\hline Alfalfa & 203.6 \\
\hline Cottonseed meal & 401.8 \\
\hline Ground sorghum & 272.3 \\
\hline Corn dried distillers' grain & 81.4 \\
\hline Corn gluten & 20.4 \\
\hline Calcium carbonate & 10.1 \\
\hline Salt & 5.2 \\
\hline Mineral premix ${ }^{1}$ & 5.2 \\
\hline \multicolumn{2}{|c|}{ Calculated chemical composition ( $\left.\mathrm{g} \mathrm{kg}^{-1} \mathrm{DM}\right)$} \\
\hline Crude protein & 266.4 \\
\hline Metabolizable energy $\left(\mathrm{Mcal} \mathrm{kg}^{-1}\right)$ & 2.61 \\
\hline $\mathrm{Ca}$ & 8.5 \\
\hline $\mathrm{P}$ & 6.9 \\
\hline
\end{tabular}

Table 3 - Adjustment of cull pinto bean level in the supplement of CB50 group during lactation

\begin{tabular}{lcc}
\hline \multirow{2}{*}{ Item } & \multicolumn{2}{c}{ Treatment $^{-}$} \\
\cline { 2 - 3 } & Initial supplement $^{1}$ & Adjustment $^{2}$ \\
\hline Ingredient $\left(\mathrm{g} \mathrm{kg}^{-1} \mathrm{DM}\right)$ & 515.0 & 436.3 \\
Cull pinto beans & 251.0 & 280.9 \\
Ground sorghum & 51.0 & 62.1 \\
Corn dried distillers' grain & 159.0 & 193.4 \\
Cottonseed meal & 12.0 & 12.1 \\
Salt & 12.0 & 12.1 \\
Mineral premix & \\
& & \\
Calculated chemical composition $\left(\mathrm{g} \mathrm{kg}^{-1} \mathrm{DM}\right)$ & 218.0 \\
Crude protein & 218.0 & 2.8 \\
Metabolizable energy (Mcal $\left.\mathrm{kg}^{-1}\right)$ & 2.8 & 2.2 \\
Ca & 2.1 & 5.1 \\
$\mathrm{P}$ & 5.0 & \\
\hline
\end{tabular}

${ }^{1} \mathrm{CB} 50$ supplement containing $500 \mathrm{~g} \mathrm{~kg}^{-1}$ of cull pinto beans.

${ }^{2} \mathrm{CB} 50$ supplement adjusted to $400 \mathrm{~g} \mathrm{~kg}^{-1}$ of cull pinto beans in the supplement

${ }^{3}$ Mineral premix: P, $120 \mathrm{~g} \mathrm{~kg}^{-1}$; Ca, $115 \mathrm{~g} \mathrm{~kg}^{-1}$; Mg, $6 \mathrm{~g} \mathrm{~kg}^{-1} ; \mathrm{Mn}, 2160 \mathrm{ppm}$;

Zn, 2850 ppm; Fe, 580 ppm; Cu, 1100 ppm; I, 102 ppm; Co, 13 ppm; Se, 9 ppm;

vitamin A, $220000 \mathrm{IU} \mathrm{kg}^{-1}$; and vitamin E, $245000 \mathrm{IU} \mathrm{kg}^{-1}$. days for fecal collections. Fecal samples were taken directly from the rectum four times a day as follows: day 1 , at 08.00 , $10.00,12.00$, and $14.00 \mathrm{~h}$; day 2 , at $16.00,18.00,20.00$, and $22.00 \mathrm{~h}$; and day 3 , at $00.00,02.00,04.00$, and $06.00 \mathrm{~h}$. Individual fecal samples weighed approximately $50 \mathrm{~g}$ (wet basis) and were composited for analysis. Then, samples were stored at $-20^{\circ} \mathrm{C}$ for further drying in a forced-air oven $\left(60{ }^{\circ} \mathrm{C}\right)$ for five days. Feed, refusals, and fecal samples were ground in a Wiley mill (1-mm screen) and analyzed for $\mathrm{DM}, \mathrm{OM}, \mathrm{CP}, \mathrm{ADF}$, and NDF as described previously. Feed and fecal samples were incubated by DAISY ${ }^{\mathrm{II}}$ system (Ankom Technology Corp. Fairport, NY) during five days (Mabjeesh et al., 2000). After incubation, bags were washed four times with cold water during $5 \mathrm{~min}$ and then dried at $60{ }^{\circ} \mathrm{C}$ during $24 \mathrm{~h}$. Concentration of ADF was determined in the bag residue to calculate the percentage of indigestible ADF (IADF) (Penning and Johnson, 1983).

Apparent DM digestibility was predicted using insoluble ADF according to the formula proposed by Schneider and Flatt (1975): DMD $=(100-(100 \times(\%$ IADF in feed/\% IADF in feces))). Apparent digestibility of CP and NDF were calculated using the following formula: $\mathrm{ND}=(100-(100 \times((\% \mathrm{IADF}$ in feed $/ \%$ IADF in feces $)$ $\times(\%$ of nutrient in feces $/ \%$ of nutrient in feed $)))$ ), in which $\mathrm{DMD}=$ digestibility of dry matter; IADF $=$ indigestible acid detergent fiber; and ND = nutrient digestibility.

The same animals used in the digestibility trial were used for non-esterified fatty acid (NEFA) measurements. Blood samples were obtained by jugular puncture and collected into tubes that contained Na2EDTA $(1 \mathrm{~g} / \mathrm{L})$ as anticoagulant and immediately placed on ice (five days before lambing and on days 20,40 , and 60 post-partum). Then, samples were centrifuged at $2000 \times g$ at $4{ }^{\circ} \mathrm{C}$ for 15 min (Dunshea and Bell, 1988) and the plasma was harvested and stored at $-20^{\circ} \mathrm{C}$. Non-esterified fatty acids in plasma were isolated according to Glaser et al. (2010). The gas chromatography (Claurus 400, Perkin Elmer; Supelco 24110-V SP+M2080 Column, $30 \mathrm{~m} \times 0.25 \mathrm{~mm}, 0.2 \mu \mathrm{m}$ FILM) was used to identify and quantify palmitic, estearic, and oleic acids representing more than $0.90 \mathrm{~kg} \mathrm{~kg}^{-1}$ of the total NEFA in ewes (Pethick et al., 1983).

Data for changes in body weight, BCS, NEFA plasma concentration, DMI, and digestibility of DM, CP, and NDF, were analyzed in a complete randomized design with repeated measure in time by MIXED procedure of SAS (Statistical Analysis System, version 9.1.3). For changes in body weight, BCS, and DMI, the pen was considered the experimental unit. For nutrient digestibility and NEFA concentration in plasma, ewe was considered the experimental unit. When significant $(\mathrm{P}<0.05)$, F-statistics 
were noted and means were separated using differences of least square means.

The mathematical model used was:

$$
\mathrm{y}_{\mathrm{ijkm}}=\mu+\tau_{\mathrm{i}}+\rho_{\mathrm{j}}+\sigma_{\mathrm{k}}+\mathrm{a}_{\mathrm{m}}+\Theta_{\mathrm{ik}}+\Theta_{\mathrm{ij}}+\Theta_{\mathrm{ijk}}+\mathrm{e}_{\mathrm{ijkm}},
$$

in which $\mathrm{y}_{\mathrm{ijkm}}=$ observed value of the variable that received the level of CPB i, day j, kind of ewe (multiparous or primiparous) $\mathrm{k}$, and experimental unit; $\mu=$ overall mean; $\tau_{\mathrm{i}}=$ dietary level of CPB effect; $\rho_{\mathrm{j}}=$ effect of the day of measurement; $\sigma_{k}=$ effect of kind of ewe (multiparous or primiparous); $\Theta_{\mathrm{ik}}=$ interaction between level of $\mathrm{CPB}$ and effect of kind of ewe; $\mathrm{a}_{\mathrm{m}}=$ experimental unit into treatment; $\Theta_{\mathrm{ij}}=$ interaction between level of CPB and effect of the day; $\Theta_{\mathrm{ijk}}=$ interaction among level of CPB, kind of ewe, and effect of the day; and $\mathrm{e}_{\mathrm{ijkm}}=$ random error associated with each observation.

On the other hand, data for LBW and LWW were analyzed by a completely randomized design using GLM procedure of SAS. When significant $(\mathrm{P}<0.05)$, F-statistics were noted and means were separated using linear and quadratic contrast.

The mathematical model used was:

$$
\mathrm{y}_{\mathrm{ijk}}=\mu+\tau_{\mathrm{i}}+\rho_{\mathrm{j}}+\sigma_{\mathrm{k}}+\mathrm{e}_{\mathrm{ijk}} \text {, }
$$

in which $\mathrm{y}_{\mathrm{ijk}}=$ observed value of the variable that received the level of CPB i, kind of ewe (multiparous or primiparous) $j$, and kind of pregnancy (single, twins, triplets, and quadruplets) $\mathrm{k}$; and $\mathrm{e}_{\mathrm{ijk}}=$ random error associated with each observation.

\section{Results and Discussion}

One characteristic of $\mathrm{CPB}$ is its high content of $\mathrm{CP}$ (higher than $200 \mathrm{~g} \mathrm{~kg}^{-1}$ of DM) (Table 4). There were no differences in body weight change or in BCS among treatments during late pregnancy $(\mathrm{P}>0.05)$ and lactation $(\mathrm{P}>0.05)$ (Table 5). Similar results were reported by Stanford et al. (1999). The inclusion of CPB in the supplement in a $400 \mathrm{~g} \mathrm{~kg}^{-1}$ level allowed ewes to maintain their body weight without diarrhea. This is an important factor to producers to increase profitability when the price of this ingredient is low. Plasma concentration of NEFA was similar $(\mathrm{P}>0.05)$ among treatments. In this study, it was observed that plasma concentration of NEFA was greater during lactation than in pregnancy (Table 6), which suggests that ewes were in a higher negative energy balance during pregnancy. Treatment $\times$ day interaction was found $(\mathrm{P}<0.05)$ for $\mathrm{DMI}$ during late pregnancy. Data showed differences $(\mathrm{P}<0.05)$ during day 115 and 130 of pregnancy, but no differences $(\mathrm{P}>0.05)$ were found among treatments (Table 7). To our knowledge, available information about pregnant and lactating ewes fed legume grains is limited.
At the end of pregnancy, CPB supplementation affected DMI, and treatments were different $(\mathrm{P}<0.05)$ (Table 7). However, during lactation, no differences $(\mathrm{P}>0.05)$ were found among treatments (Table 7).

For lamb birth weight, no effects of interaction were found ( $\mathrm{P}>0.05)$. Results showed differences $(\mathrm{P}<0.01)$ among treatments (control: $3.25 \pm 0.16$; CB25: $3.09 \pm 0.16$; CB50: $3.28 \pm 0.16)$ and had a quadratic effect $(\mathrm{P}<0.05)$. Lambs of single pregnancy were heavier (single: $4.22 \pm 0.12$; twins: $3.42 \pm 0.12$; triplets: $2.64 \pm 0.12$; quadruplets: $2.56 \pm 0.12$ ) than those who came from multiple pregnancies. Lamb weaning weight was not affected $(\mathrm{P}>0.05)$ by treatment (control: 17.1 \pm 0.8 ; CB25: 17.2 \pm 0.8 ; CB50: 17.2 \pm 0.8 ).

The treatment $\times$ day interaction was found $(\mathrm{P}<0.05)$ for digestibility of DM, CP, and NDF. During lactation, differences were found $(\mathrm{P}<0.01)$ on day 30 post-calving and the control group had greater digestibility than CB25 and CB50 groups (Table 8 ). The treatment $\times$ day interaction was found $(\mathrm{P}<0.05)$ for digestibility of $\mathrm{DM}, \mathrm{CP}$, and NDF. During lactation, differences were found $(\mathrm{P}<0.01)$ on day 30 post-lambing and control group had greater digestibility than CB25 and CB50 groups (Table 8). No differences $(\mathrm{P}>0.05)$ were found for this variable on the day 60 of lactation. Digestibility of $\mathrm{CP}$ during lactation on the day 30 post-weaning was greater $(\mathrm{P}<0.01)$ for control and CB25 groups than CB50 (Table 8). On day 60 of lactation, the analysis showed that digestibility of $\mathrm{CP}$ was greater

Table 4 - Nutritive value and mineral profile of cull pinto beans (DM basis)

\begin{tabular}{lc}
\hline Item & DM basis \\
\hline Nutrient $\left(\mathrm{g} \mathrm{kg}^{-1} \mathrm{DM}\right)$ & \\
Dry matter $(\mathrm{DM})$ & 918.0 \\
Organic matter & 850.0 \\
Crude protein & 212.0 \\
Crude fiber & 66.0 \\
Ether extract & 19.0 \\
Ashes & 68.0 \\
Neutral detergent fiber & 236.0 \\
Acid detergent fiber & 57.0 \\
Nitrogen-free extract & 553.0 \\
Total digestible nutrients & 850.0 \\
Digestible energy $\left(\mathrm{Mcal} \mathrm{kg}^{-1} \mathrm{DM}\right)$ & 3.75 \\
$\mathrm{Metabolizable} \mathrm{energy}\left(\mathrm{Mcal} \mathrm{kg}^{-1} \mathrm{DM}\right)$ & 3.08 \\
& \\
$\mathrm{Mineral} \mathrm{profile}$ & \\
$\mathrm{Ca}\left(\mathrm{g} \mathrm{kg}^{-1}\right)$ & 1.8 \\
$\mathrm{P}\left(\mathrm{g} \mathrm{kg}^{-1}\right)$ & 3.0 \\
$\mathrm{Co}\left(\mathrm{mg} \mathrm{kg}^{-1}\right)$ & $<0.68$ \\
$\mathrm{Cu}\left(\mathrm{mg} \mathrm{kg}^{-1}\right)$ & 4.76 \\
$\mathrm{Fe}\left(\mathrm{mg} \mathrm{kg}^{-1}\right)$ & 8.4 \\
$\mathrm{Mg}\left(\mathrm{mg} \mathrm{kg}^{-1}\right)$ & 0.17 \\
$\mathrm{Mn}\left(\mathrm{mg} \mathrm{kg}^{-1}\right)$ & 22.9 \\
$\mathrm{~S}\left(\mathrm{~g} \mathrm{~kg}^{-1}\right)$ & 1.9 \\
$\mathrm{Se}\left(\mathrm{mg} \mathrm{kg}^{-1}\right)$ & $<7.25$ \\
$\mathrm{Zn}\left(\mathrm{mg} \mathrm{kg}^{-1}\right)$ & 25.09 \\
\hline
\end{tabular}


Table 5 - Least square means $( \pm \mathrm{SE})$ for change in body weight $(\mathrm{kg})$ and body condition score of hair ewes fed three levels of cull pinto beans $(\mathrm{CPB})$ in the supplement

\begin{tabular}{|c|c|c|c|c|c|c|c|c|c|c|}
\hline \multirow{3}{*}{ Day } & \multicolumn{5}{|c|}{ Change in body weight } & \multicolumn{5}{|c|}{ Body condition score } \\
\hline & \multicolumn{3}{|c|}{ Treatment $^{1}$} & \multirow{2}{*}{$\mathrm{SE}$} & \multirow{2}{*}{ P-value } & \multicolumn{3}{|c|}{ Treatment $^{1}$} & \multirow{2}{*}{$\mathrm{SE}$} & \multirow{2}{*}{ P-value } \\
\hline & Control & $\mathrm{CB} 25$ & CB50 & & & Control & CB25 & CB50 & & \\
\hline $8^{2}$ & 44.0 & 42.7 & 42.8 & 1 & 0.3671 & 2.57 & 2.66 & 2.59 & 0.04 & 0.0972 \\
\hline $9^{3}$ & 41.8 & 39.6 & 40.2 & 1 & 0.1227 & 2.71 & 2.69 & 2.67 & 0.04 & 0.4583 \\
\hline $23^{3}$ & 40.7 & 40.8 & 39.5 & 1 & 0.3514 & 2.8 & 2.87 & 2.8 & 0.04 & 0.1957 \\
\hline $37^{3}$ & 42.2 & 40.9 & 41.1 & 1 & 0.3708 & 2.82 & 2.89 & 2.83 & 0.04 & 0.1957 \\
\hline $51^{3}$ & 41.6 & 41.4 & 40.9 & 1 & 0.6069 & 2.83 & 2.89 & 2.84 & 0.04 & 0.2177 \\
\hline $65^{3}$ & 39.3 & 39.2 & 38.8 & 1 & 0.7273 & 2.82 & 2.81 & 2.83 & 0.04 & 0.8045 \\
\hline Total $^{4}$ & 41.6 & 40.8 & 40.6 & 0.92 & 0.6923 & 2.75 & 2.8 & 2.76 & 0.03 & 0.4531 \\
\hline
\end{tabular}

${ }^{1}$ Treatments: Control $=0 \mathrm{~g} \mathrm{~kg}^{-1}$ of CPB in the supplement; $\mathrm{CB} 25=250 \mathrm{~g} \mathrm{~kg}^{-1}$ of CPB in the supplement; $\mathrm{CB} 50=500 \mathrm{~g} \mathrm{~kg}^{-1}$ of CPB in the supplement.

${ }^{2}$ Day 8 before calving.

${ }^{3}$ Day after calving.

${ }^{4}$ Includes data from pregnancy and lactation.

$\mathrm{SE}$ - standard error.

for CB25 group (Table 8). Data for digestibility of NDF showed differences $(\mathrm{P}<0.01)$ among treatments on day 60 and was greater for CB25 (Table 8). These differences in fiber digestibility might be associated to the differences in the digestibility of DM and $\mathrm{CP}$.

The use of CPB in sheep diets can help to reduce the quantity of soybean meal, cottonseed meal, and dried distiller's grains, among others. Since changes in body weight of the ewes and the weaning weight of lambs did not differ among treatments, it could be inferred that there was no effect of lectins on digestion efficiency and nutrient absorption. Similarly, the inclusion of chickpeas (Cicer arientinum) in diets of lactating ewes and lambs did not affect changes in body weight and average daily gain, respectively, compared with control groups (Hadjipanayiotou, 2002; Christodoulou et al., 2005). In sheep, BCS is related to body weight; Sanson et al. (1993) reported that for each unit of change in BCS, a change of $5.06 \mathrm{~kg}$ of body weight is necessary. A greater difference in change of body weight among treatments was $2.4 \mathrm{~kg}$. Sanson et al. (1993) found that BCS explains the variation in carcass fat percentage. Field et al. (1985) discussed that fat in sheep represents energy depots, which are used when energy intake is not enough to cover energy requirements, especially at the end of pregnancy or during lactation when ewes are in a negative energy balance. High concentration of NEFA in plasma is present due to a depot fat mobilization, which compensate the low energy intake (Kouakou et al., 2008). This study expected to find differences among treatments in plasma concentration of NEFA, even when supplements were isoenergetic because of the presence of antinutritional factors that could affect nutrient absorption. Elevated plasma concentration of NEFA occurs in periods with high rate of lipolysis in adipose tissue
Table 6 - Least square means $( \pm \mathrm{SE})$ for concentration of nonesterified fatty acids in plasma $\left(\mathrm{mM} \mathrm{L}^{-1}\right)$ of hair ewes during pregnancy and lactation fed three levels of cull pinto beans (CPB) in the supplement

\begin{tabular}{|c|c|c|c|c|c|}
\hline \multirow{2}{*}{ Day } & \multicolumn{3}{|c|}{ Treatment $^{1}$} & \multirow{2}{*}{ SE } & \multirow{2}{*}{ P-value } \\
\hline & Control & CB25 & CB50 & & \\
\hline $5^{2}$ & 10.63 & 9.48 & 10.48 & 1.13 & 0.4795 \\
\hline $20^{3}$ & 11.66 & 11.89 & 12.13 & 1.13 & 0.7740 \\
\hline $40^{3}$ & 11.33 & 11.36 & 11.94 & 1.13 & 0.7196 \\
\hline $60^{3}$ & 13.66 & 13.19 & 12.97 & 1.13 & 0.6674 \\
\hline Total $^{4}$ & 11.82 & 11.48 & 11.88 & 0.58 & 0.8705 \\
\hline
\end{tabular}

${ }^{1}$ Treatments: Control $=0 \mathrm{~g} \mathrm{~kg}^{-1}$ of CPB in the supplement; $\mathrm{CB} 25=250 \mathrm{~g} \mathrm{~kg}^{-1}$ of CPB in the supplement; $\mathrm{CB} 50=500 \mathrm{~g} \mathrm{~kg}^{-1}$ of CPB in the supplement.

${ }^{2}$ Day five before calving.

${ }^{3}$ Day after calving.

${ }^{4}$ Includes data from pregnancy and lactation.

SE - standard error.

Table 7 - Least square means $( \pm \mathrm{SE})$ for dry matter intake $(\mathrm{kg})$ of pregnant-lactating hair ewes fed three different levels of cull pinto beans (CPB)

\begin{tabular}{lccccc}
\hline \multirow{5}{*}{ Day } & \multicolumn{5}{c}{ Treatment $^{1}$} \\
\cline { 2 - 4 } & Control & CB25 & CB50 & P-value \\
\hline \multicolumn{5}{c}{ Pregnancy } \\
$115^{2}$ & $1.52 \mathrm{a}$ & $1.44 \mathrm{ab}$ & $1.40 \mathrm{~b}$ & 0.03 & 0.0221 \\
$130^{2}$ & $1.79 \mathrm{a}$ & $1.69 \mathrm{~b}$ & $1.66 \mathrm{~b}$ & 0.03 & 0.0121 \\
$145^{2}$ & $1.78 \mathrm{a}$ & $1.73 \mathrm{a}$ & $1.71 \mathrm{a}$ & 0.03 & 0.2194 \\
Total $^{3}$ & $1.69 \mathrm{a}$ & $1.62 \mathrm{ab}$ & $1.59 \mathrm{~b}$ & 0.03 & 0.0318 \\
\multicolumn{5}{c}{ Lactation } \\
$17^{4}$ & $2.17 \mathrm{a}$ & $2.01 \mathrm{a}$ & $2.19 \mathrm{a}$ & 0.09 & 0.1839 \\
$34^{4}$ & $2.45 \mathrm{a}$ & $2.27 \mathrm{a}$ & $2.47 \mathrm{a}$ & 0.09 & 0.1381 \\
$46^{4}$ & $2.62 \mathrm{a}$ & $2.51 \mathrm{a}$ & $2.62 \mathrm{a}$ & 0.09 & 0.3926 \\
$60^{4}$ & $2.35 \mathrm{a}$ & $2.35 \mathrm{a}$ & $2.33 \mathrm{a}$ & 0.09 & 0.8840 \\
Total $^{5}$ & $2.39 \mathrm{a}$ & $2.28 \mathrm{a}$ & $2.40 \mathrm{a}$ & 0.08 & 0.0639 \\
\hline
\end{tabular}

${ }^{1}$ Treatments: Control $=0 \mathrm{~g} \mathrm{~kg}^{-1}$ of $\mathrm{CPB}$ in the supplement; $\mathrm{CB} 25=250 \mathrm{~g} \mathrm{~kg}^{-1}$ of CPB in the supplement; CB50 $=500 \mathrm{~g} \mathrm{~kg}^{-1}$ of CPB in the supplement.

${ }^{2}$ Day of pregnancy.

${ }^{3}$ Includes total data from late pregnancy.

${ }^{4}$ Day after calving.

${ }^{5}$ Includes total data from lactation.

SE - standard error.

Means in the same row with different lowercase letters are significantly different $(\mathrm{P} \leq 0.05)$. 
(Celi et al., 2008) and indicates that animals are in catabolic state. In this study, when supplementation began, ewes were in a state of undernutrition. Plasma concentration of NEFA during pregnancy and lactation could be associated with the low nutrient intake in early and middle pregnancy. Duehlmeier et al. (2011) claimed that low energy intake in late pregnancy can produce high plasma concentrations of NEFA in lactating ewes.

Dry matter intake has been reported when ruminants are fed legume grains. Williams et al. (1984) and Rush et al. (1998) found that, as the level of beans increased in the diet for steers, DMI decreased. Soto-Navarro et al. (2004) reported similar DMI when field peas (Pisum Sativum) replaced wheat middlings, soybean hulls, and barley malt sprouts in the ration of steers. Gilbery et al. (2007) reported that the inclusion of chickpeas (Cicer arientinum), field peas (Pisum Sativum), and lentil screenings (Lens culinaris) did not affect DMI when those ingredients replaced dry-rolled corn and canola meal in the diet of steers, while Stanford et al. (1999) reported linear decreases in DMI of lambs fed $750 \mathrm{~g} \mathrm{~kg}^{-1}$ concentrate diets, in which lentil screenings (Lens culinaris) replaced barley and canola meal at 125, 250, and $330 \mathrm{~g} \mathrm{~kg}^{-1}$ of diet DM. This study observed a different effect of CPB level on DMI in both physiological states in which ewes received different diets. These results correspond to previous findings, observing that in ruminants, DMI and

Table 8 - Least square means $( \pm \mathrm{SE})$ for digestibility $\left(\mathrm{g} \mathrm{kg}^{-1}\right)$ of dry matter, crude protein, and neutral detergent fiber of pregnant-lactating ewes fed three levels of cull pinto beans

\begin{tabular}{|c|c|c|c|c|c|}
\hline \multirow{2}{*}{ Day } & \multicolumn{3}{|c|}{ Treatment $^{1}$} & \multirow{2}{*}{ SE } & \multirow{2}{*}{ P-value } \\
\hline & Control & CB25 & CB50 & & \\
\hline \multicolumn{6}{|c|}{ Dry matter digestibility } \\
\hline $8^{2}$ & $407.1 \mathrm{a}$ & $397.8 \mathrm{a}$ & $418.3 \mathrm{a}$ & 19.4 & 0.4613 \\
\hline $30^{3}$ & $411.4 \mathrm{a}$ & $395.7 \mathrm{a}$ & $317.4 b$ & 20.9 & 0.0017 \\
\hline $60^{3}$ & $541.8 \mathrm{a}$ & $570.2 \mathrm{a}$ & $525.4 \mathrm{a}$ & 20.9 & 0.1268 \\
\hline Total $^{4}$ & $453.4 \mathrm{a}$ & $454.5 \mathrm{a}$ & $420.3 a$ & 12.9 & 0.1026 \\
\hline \multicolumn{6}{|c|}{ Crude protein digestibility } \\
\hline $8^{2}$ & $363.6 \mathrm{a}$ & $342.8 \mathrm{a}$ & $390.3 a$ & 26.0 & 0.2068 \\
\hline $30^{3}$ & $432.9 \mathrm{a}$ & $418.7 \mathrm{a}$ & $285.9 \mathrm{~b}$ & 34.0 & 0.0016 \\
\hline $60^{3}$ & $572.5 b$ & $635.3 \mathrm{a}$ & $558.1 \mathrm{~b}$ & 28.0 & 0.0528 \\
\hline Total $^{4}$ & $456.3 \mathrm{a}$ & $465.6 \mathrm{a}$ & $411.4 b$ & 15.0 & 0.0563 \\
\hline \multicolumn{6}{|c|}{ Neutral detergent fiber digestibility } \\
\hline $8^{2}$ & $350.2 \mathrm{a}$ & $322.4 \mathrm{a}$ & $357.6 \mathrm{a}$ & 20.1 & 0.2247 \\
\hline $30^{3}$ & $299.3 \mathrm{a}$ & $309.9 \mathrm{a}$ & $283.2 \mathrm{a}$ & 21.7 & 0.1547 \\
\hline $60^{3}$ & $273.6 b$ & $420.9 \mathrm{a}$ & $328.6 \mathrm{ab}$ & 21.7 & 0.0037 \\
\hline Total $^{4}$ & $341.0 \mathrm{a}$ & $351.1 \mathrm{a}$ & $323.1 \mathrm{a}$ & 13.7 & 0.3394 \\
\hline
\end{tabular}

${ }^{1}$ Treatments: Control $=0 \mathrm{~g} \mathrm{~kg}^{-1}$ of CPB in the supplement; $\mathrm{CB} 25=250 \mathrm{~g} \mathrm{~kg}^{-1}$ of $\mathrm{CPB}$ in the supplement; $\mathrm{CB} 50=500 \mathrm{~g} \mathrm{~kg}^{-1}$ of CPB in the supplement.

${ }^{2}$ Day before calving.

${ }^{3}$ Day after calving.

${ }^{4}$ Includes data from pregnancy and lactation.

$\mathrm{SE}$ - standard error.

Means in the same row with different lowercase letters are significantly different $(\mathrm{P} \leq 0.05)$. energy intake can change because of differences in diet composition or physiological state (Allen et al., 2009).

As expected, lambs from multiparous ewes $(3.34 \pm 0.21)$ were heavier than lambs from primiparous $(3.08 \pm 0.21)$. Fetal metabolism and growth depend on the nutrients crossing the placenta; therefore, ewes must adapt its metabolism to maintain this draining of substrates. Glucose, which is the main carbohydrate crossing the placenta is transported by facilitative diffusion according to a concentration-dependent kinetics, whereas amino acids are transported through energy-dependent processes via selective transporters (Herrera, 2002). Differences among treatments for LBW can be explained due to fetal growth reduction for ewes in control and CB25 treatment during the last 30 days of pregnancy when there is a limit of nutrients crossing through the placenta, affecting nutrient availability for the fetus (Fowden et al., 1998). Ewe nutrition plan has an effect on milk production, which affects lamb performance. Colostrum intake is positively related with postnatal performance (Massimini et al., 2006). Because of the greater LBW of CB50 group, a heavier LWW for lambs of CB50 group was expected; nonetheless, lamb performance was similar among treatments. It was assumed that during lactation, ewes from CB50 group had less nutrient absorption due to the effect of antinutritional factors.

At the end of pregnancy, the inclusion of CPB in the supplements was not enough to provide the antinutritional factors necessary to cause digestive disorders and to affect digestibility of DM; similarly, Williams et al. (1984) did not find differences among treatments when yearling cattle fed raw kidney beans. Once supplementation of lactation started, we noticed the presence of diarrhea in the primiparous ewes from CB50 group; for this reason, an adjustment to a $400 \mathrm{~g} \mathrm{~kg}^{-1}$ in CPB level was made, although digestibility of DM was still affected even with the $400 \mathrm{~g} \mathrm{~kg}^{-1}$ inclusion of CPB in the day 30 of lactation. Differences for digestibility of DM within the period of the study might be related to a slow adaptation to the presence of antinutritional factors from ruminal microorganisms. Likewise, Stanford et al. (1999) reported a linear decrease in the digestibility of $\mathrm{OM}$ as the level of lentil screenings (Lens culinaris) increased in the diet of ewes and lambs, attributing this reduction to the presence of antinutritional factors in lentil screenings. In another study, Singh et al. (2006) did not find differences in digestibility of DM when different levels of cowpea legume grains were given to lambs. The reduction in the digestibility of $\mathrm{CP}$ might be related to the antinutritional factors contained in $\mathrm{CPB}$. The most important antinutritional factors in legume 
grains are lectins and protease inhibitors (Paduano et al. 1995). Enzyme inhibitors can diminish protein digestibility and lectins can reduce nutrient absorption (Lajolo and Genovese, 2002). Little information for digestibility of $\mathrm{NDF}$ is available when ruminants receive grain legumes in their diet. Singh et al. (2006) reported no differences for digestibility of NDF when lambs were fed different levels of cowpea grains. Other authors (Patterson et al., 1999) did not find differences on forage NDF digestion rate when cull beans were included in diets of steers.

\section{Conclusions}

Inclusion of cull pinto beans in supplement for pregnant-lactating ewes is an alternative in sheep feeding; however, its inclusion in more than $400 \mathrm{~g} \mathrm{~kg}^{-1}$ during lactation can cause digestive disorders. Inclusion of cull pinto beans in supplements can affect digestibility of crude protein and dry matter. Nonetheless, these alterations in nutrient digestibility do not affect animal performance. The use of cull pinto beans is recommendable in ewe supplementation.

\section{Acknowledgments}

Appreciation is expressed to Fundación Produce Chihuahua for its financial support.

\section{References}

Allen, M. S.; Bradford, B. J. and Oba, M. 2009. Board-invited review: the hepatic oxidation theory of the control of feed intake and its application to ruminants. Journal of Animal Science 87:3317-3334.

AOAC- Association of Official Analytical Chemistry. 2003. Official methods of analysis. 17th ed. Association of Official Analytical Chemistry, Arlington, VA.

Castillo, R. F. 2011. Uso de frijol de desecho en la alimentación de ovinos. Disertación (D. Ph.). Universidad Autónoma de Chihuahua, Chihuahua, México.

Celi, P.; Di Trana, A. and Claps, S. 2008. Effects of perniatal nutrition on lactational performance, metabolic and hormonal profiles of dairy goats and respective kids. Small Ruminant Research 79:129-136.

Christodoulou, V.; Bampidis, V. A.; Hucko, B.; Ploumi, K.; Iliads, C.; Robinson, P. H. and Mudrik, Z. 2005. Nutritional value of chickpeas in rations of lactating ewes and growing lambs. Animal Feed Science and Technology 118:229-241.

Dixon, R. M. and Hosking, B. J. 1992. Nutritional value of grain legumes for ruminants. Nutrition Research Reviews 5:19-43.

Duehlmeier, R.; Fluegge, I.; Schwert, B.; Parvizi, N. and Ganter, M. 2011. Metabolic adaptations to pregnancy and lactation in German Blackheaded Mutton and Finn sheep ewes with different susceptibilities to pregnancy toxemia. Small Ruminant Research 96:178-184.
Dunshea, F. R. and Bell. A. W. 1988. Relations between plasma nonesterified fatty acid metabolism and body tissue movilization during chronic under nutrition in goats. British Journal of Nutrition 60:633-644.

Field, R. A.; Bass, J. J.; Kirton, A. H.; Fowke, P. J. and Duganzich, D. M. 1985. Distribution of ether extract, moisture, protein, and ash in dissected tissues from ovines carcasses. Journal of Animal Science 60:977-988.

Fowden, A. L.; Mundy, L. and Silver, M. 1998. Developmental regulation of glucogenesis in the sheep fetus during late gestation. The Journal of Phisiology 508:937-947.

Gilbery, T. C.; Lardy, G. P.; Soto-Navarro, S. A.; Bauer, M. L. and Anderson, V. L. 2007. Effect of field peas, chickpeas, and lentils on rumen fermentation, digestion, microbial protein synthesis, and feedlot performance in receiving diets for beef cattle. Journal of Animal Science 85:3045-3053.

Glaser, C.; Demmelmair, H. and Koletzko, B. 2010. High-throughput analysis of total plasma fatty acid composition with direct in situ transesterification. PlosOne 5:e12045.

Hadjipanayiotou, M. 2002. Replacement of soybean meal and barley grain by chickpeas in lamb and kid fattening diets. Animal Feed Science and Technology 96:103-109.

Herrera, E. 2002. Implications of dietary fatty acids during pregnancy on placental, fetal and postnatal development. A review. Placenta 23:S9-S19

Kouakou, B.; Gazal, O. S.; Terrill, T. H.; Kannan, G.; Gelaye, S. and Amoah, E. A. 2008. Digestibility, hormones and blood metabolites in dairy bucks subjected to underfeeding and refeeding. Small Ruminant Research 75:171-176.

Lajolo, F. M. and Genovesse, M. I. 2002. Nutritional significance of lectin and enzyme inhibitors from legumes. Journal of Agricultural and Food Chemistry 50:6592-6598.

Mabjeesh, S. J.; Cohen, M. and Arieli, A. 2000. In vitro methods for measuring the dry matter digestibility of ruminant feedstuffs: Comparison of methods and inoculums source. Journal of Dairy Science 83:2289-2294.

Massimini, G.; Britti, D.; Peli, A. and Cinotti, S. 2006. Effect of passive transfer status on preweaning growth performance of dairy lambs. Journal of the American Veterinary Medical Association 229:111-115.

Mejía, E. G.; Guzmán-Maldonado, S. H.; Acosta-Gallegos, J. A.; Reynoso-Camacho, R.; Ramírez-Rodríguez, E.; Pons-Hernández, J. L.; González-Chavira, M. M.; Castellanos, J. Z. and Kelly, J. D. 2003. Effect of cultivar and growing location of tripsin inhibitors, tannins and lectins of common beans (Phaseolus vulgaris $\mathrm{L}$ ) grown in the semiarid highlands of Mexico. Journal of Agricultural and Food Chemistry 51:5962-5966.

NRC - National Research Council. 2006. Nutrient requirement of small ruminants, sheep, goats, cervids and New World Camelids. The National Academy Press, Washington, DC.

Norma Oficial Mexicana NOM-024-ZOO-1995, Especificaciones y características zoosanitarias para el transporte de animales, sus productos y subproductos, productos químicos, farmacéuticos, biológicos y alimenticios para uso de animales o consumo por éstos. Diario Oficial de la Federación, 16 de Octubre de 1995.

Norma Oficial Mexicana NOM-051-ZOO-1995, Norma para trato humanitario en la movilización de animales. Diario Oficial de la Federación, 23 de Marzo de 1995.

Paduano, D. C.; Dixon, R. M.; Domingo, J. A and Holmes, J. H. G. 1995. Lupin (Lupin angustifolius), cowpea (Vigna unguiculata) and navy beans (Phaseolus vulgaris) seeds as supplements for sheep fed low quality roughage. Animal Feed Science and Technology 53:55-69. 
Patterson, H. H.; Whittier, J. C. and Rittenhouse, L. R. 1999. Effect of cull beans, sunflower meal, and canola meal as protein supplements to beef steers consuming grass hay on in situ digestion kinetics. The Professional Animal Scientist 15:185-190.

Penning, P. D. and Johnson, R. H. 1983. The use of internal markers to estimate herbage digestibility and intake. 2. Indigestible acid detergent fibre. Journal of Agricultural Science 100:133-138.

Pethick, D. W.; Lindsay, D. B.; Barker, P. J. and Northrop, J. 1983. The metabolism of circulating none esterified fatty acids by the whole animal, hand-limb, muscle and uterus of pregnant ewes. British Journal of Nutrition 49:129-143.

Russel, A. J. F.; Doney, J. M. and Gunn, G. 1969. Subjective assessment of body fat in live sheep. Journal of Agricultural Science 72:451-454.

Rush, I. G.; Weichenthal, B. and Van Pelt, B. 1998. Cull dry edible beans in growing calf rations. University of Nebraska - Lincoln. Nebraska beef cattle reports. Available: $<$ http://digitalcommons.unl. edu/animalscinbcr/356>. Accessed on: May 07, 2012.

Sanson, D. W.; West, T. R.; Tatman, W. R.; Riley, M. L.; Judkins, M. B. and Moss, G. E. 1993. Relationship of body composition of mature ewes with condition score and body weight. Journal of Animal Science 71:1112-1116.

Schneider B. H. and Flatt, W. P. 1975. Evaluation of feed trough digestibility experiments. University of Georgia Press, Athens.
Singh, S.; Kundu, S. S.; Negi, A. S. and Singh, P. N. 2006. Cowpea (Vigna unguiculata) legume grains as protein source in the ration of growing sheep. Small Ruminant Research 64:247-254.

Soto-Navarro, S. A.; Williams, G. J.; Bauer, M. L.; Lardy, G. P.; Landblom, D. G. and Caton, J. S. 2004. Effect of field pea replacement level on intake and digestion in beef steers fed byproducts-based medium concentrate diets. Journal of Animal Science 82:1855-1862.

Stanford, K.; Wallins, G. L.; Less, B. M. and Mündel. H. H. 1999. Use of lentil screenings in the diets of early weaned lambs and ewes in the second trimester of pregnancy. Animal Feed Science and Technology 81:249-264.

Van Soest, P. J.; Robertson, J. B. and Lewis, B. A. 1991. Methods for dietary fiber, neutral detergent fiber, and nonstarch polysaccharides in relation to animal nutrition. Journal of Dairy Science 74:3583-3589.

Villalobos, G.; Castillo, F.; Domínguez, D.; Castillo, H. and Ortega, J. A. 2010. Use of waste pinto bean grain on finishing hair lambs. Proceedings of Western Section of American Society of Animal Science 61:293-296.

Williams, P. E. V.; Pusztai, A. J.; Macdearmid, A. and Innes, G. M. 1984. The use of kidney beans (Phaseolus vulgaris) as protein supplement in diets for young rapidly growing beef steers. Animal Feed Science and Technology 12:1-10. 